Center for

Higher Education

Policy Studies

\title{
What makes the difference?
}

\section{Analysing the regional component of the influence of university's structural configuration on its performance}

\section{CHEPS WORKING PAPER 01/2015}

Mabel Sánchez-Barrioluengo. INGENIO (CSIC-UPV) Universitat Politècnica de València msbarrioluengo@ingenio.upv.es

Paul Benneworth. CHEPS (University of Twente)

p.benneworth@utwente.nl

Contact:

Paul Benneworth

Centre for Higher Education Policy Studies

University of Twente

P.O. Box 217

7500 AE Enschede

The Netherlands

$\mathrm{T} \quad+3153-4893263$

F +3153-4340392

E p.benneworth@utwente.nl

W www.utwente.nl/cheps 


\section{Table of Contents}

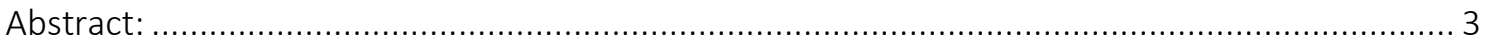

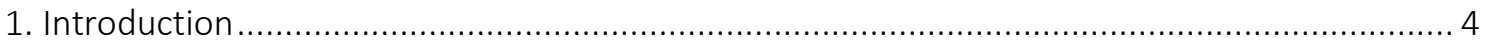

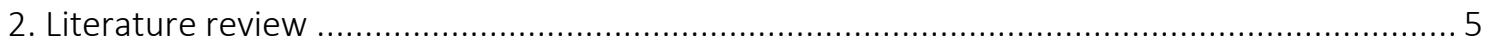

2.1. University regional contribution as localised spillovers ....................................... 6

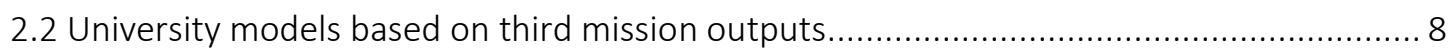

2.3 Linking localised knowledge spillovers to university structural configuration .................. 10

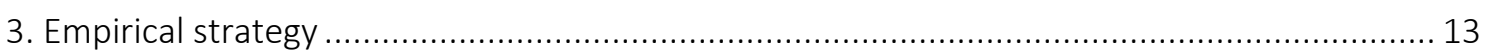

3.1 The context: UK third mission policy in HEls .............................................. 13

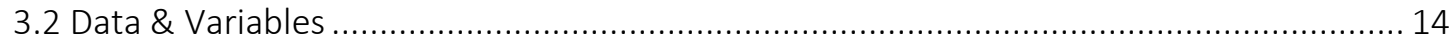

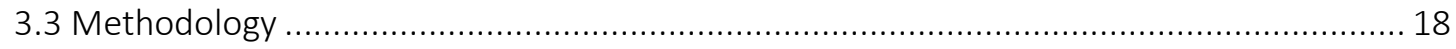

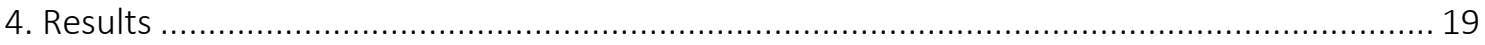

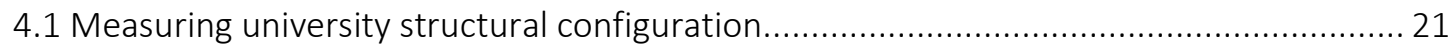

4.2 The effect of structural configuration on third mission performance across university

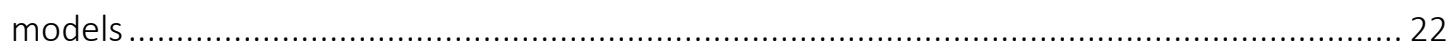

5. Universities contributions to regional upgrading processes ...................................... 25

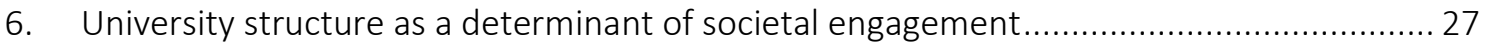

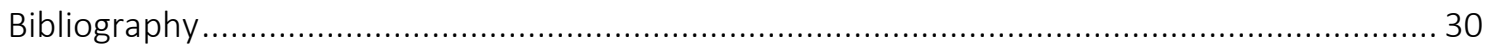




\begin{abstract}
There is an increasing interest in the analysis of how universities should maximise their specific regional contribution alongside their traditional teaching and research goals. However, due to the institutional heterogeneity it is necessary to understand the process by which universities create regional benefits, specifically on the creation of third mission outputs, and the extent to which internal institutional configuration affects the production of these benefits. To cover this gap, this study focus on the UK Higher Education sector and investigates the role played by four elements of the universities' structural configuration, namely steering core, administrative machinery, internal coupling and academic heartland, affect institutional performance in two different university models: the entrepreneurial university and the regional innovation system university model.
\end{abstract}

Keywords: entrepreneurial university; regional innovation system university; performance; internal structure; region. 


\section{Introduction}

The starting point for this paper is the explosion of interest on the role of universities in regional development in recent years (Lawton-Smith \& Bagchi-Sen, 2012; Peer \& Penker, 2014), asserting that driving regional development represents a (novel) third mission for universities alongside the first (teaching) and second (research) traditional missions (Perkmann et al., 2013). With economic development increasingly dependent on processing and exploiting knowledge capital (Capello \& Nijkamp, 2010; Huggins \& Izushi, 2013), focus has lain on the actors involved in knowledge production and exploitation (Perry \& May, 2010; Yigitcanlar, 2010; Sarimin \& Yigitcanlar, 2012). Universities' general-abstract roles in creating, transmitting, circulating, extended and phasing out knowledge has become linked with their capacity to make that knowledge available to create particular regional development benefits (Charles, 2011). There is increasing interest in optimising these two roles, maximising their specific regional contributions without comprising on their needs to pursue independent scholarship and research in wider networks (De Boer et al., 2007; Landry et al., 2010; Pinheiro et al., 2012).

But these roles cannot always seamlessly fit together (Pinheiro et al., 2012), particular where universities must balance between making their knowledge most immediately useful for users and in serving their core goals of teaching and research (Sánchez-Barrioluengo, 2014). This has become increasingly urgent given continuing pressure for universities to pursue excellence in international research networks (Cremonini et al., 2013; Perry, 2012). The deep-seated nature of this problematic is illustrated by it being over 30 years since the OECD Centre for Education Research and Innovation published their report Universities and their Communities, recommending how universities could best increase their socioeconomic contributions (CERI, 1982). Yet, three decades hence the European Commission felt impelled to publish a policy guide on universities maximising their contribution to regional smart specialisation strategies (Goddard, 2011).

This highlights the tensions between the generalities of universities offering potential regional and the practicalities of delivering concrete regional 
development activities harmoniously with core university activities (Pinheiro et al., 2012). Engaging with non-academic actors can create prima facie problems and tensions within scientific enterprises ( $c f$. Thompson, 1970; inter alia Philpott et al., 2011; Tartari and Breschi 2012). Even where universities acknowledge their societal duties, those duties may not easily be discharged (Benneworth et al., 2013). We argue more attention need be paid to how universities balance these tensions in delivering regional benefits, and particularly to how universities structure themselves to deliver those benefits.

In this paper we seek to foreground this issue of universities' internal diversity by focusing on universities' structural regional engagement configurations, such as institutional strategies, administrative machinery, support structures and academic incentives. Our overarching research question is how do universities' organisational dynamics and structural configuration affect the university's production of regional outputs distinguishing two university models: (a) the entrepreneurial university (EU) and (b) the regional innovation system university (RISU) model (see section 2). To address this we develop a quantitative analysis using the UK's Higher Education -Business \& Community Interaction (HE-BCI)survey (section 3). Our analysis explores how do these formal structures affect the production of third mission outputs (section 4). We then examine how far universities' purposive, strategic action can stimulate their contribution to regional economic development (section 5). Section 6 concludes.

\section{Literature review}

Over the past years various approaches have been developed to illuminate universities' roles in regional development reflecting different underlying models (Goldstein, 2010; Uyarra, 2010). We here distinguish two models where universities have activities targeting regional economic development, namely the entrepreneurial university (EU) and the regional innovation system university (RISU) model. The EU model claims universities promote regional development comes through their patenting, licensing and academic spin-off activities. The RISU takes a broader perspective, by including "softer" forms of knowledge transfer relating not only to direct innovation activity, but also to improving the policy, 
intermediary and cultural innovation environment (Gunasekara, 2006; Lundvall, 2007; Trippl et al., 2014).

To address our overall research question, we conceptualise university contributions to regional economic development as coming via "knowledge spillovers" (Benneworth \& Charles, 2005; Drucker \& Goldstein, 2007). Knowledge spillovers have localised dimensions, creating knowledge resources more easily accessed by physically proximate actors (Ponds et al., 2010). Given that innovation is resource-constrained, ready availability locally of certain knowledge resources can enable innovation activities drawing on those resources, thereby stimulating knowledge based regional development. To date research on university structure and regional engagement has split between small-scale case studies of organisational forms (Healy et al., 2014) alongside quantitative analyses of which kinds of universities produce regional outputs (Drucker \& Goldstein, 2007). Few analyses have directly asked how does universities' underlying internal organisation create localised spillover effects.

\subsection{University regional contribution as localised spillovers}

It is first necessary to clearly define what we mean by university regional contributions as knowledge spillovers. Universities have a very wide-ranging set of impacts on their regional contexts (CVCP, 1994; Charles \& Benneworth, 2001; OECD, 2007). We are here concerned with regional economic development, a process regulated by the supply of capital and the efficiency with which various forms of capital can be brought productively (Rodríguez-Pose, 2013). While the traditional capital factors of land, labour and machinery remain important in determining productivity levels, productivity growth is also increasingly shaped by capacity to harness new ideas (Audretsch and Keilbach, 2004). Griliches' (1979) knowledge production function defined innovative outputs as a function of innovative inputs; being the most important input here the new knowledge (Audretsch \& Feldman, 2003). In addition, Cohen and Klepper (1991; 1992) argue that the greatest source of new knowledge tends to be R\&D activities.

The knowledge production function provides a means to understand universities' (and other HEIs') regional contributions as an important producers and mobilizers 
of knowledge spillover that effects at national, regional and local level (Jaffe, 1989; Anselin et al., 1997; Audretsch et al., 2005). This conceptualises universities functions as creating positive externalities and incubating knowledge capital thereby contributing to local development. University spillovers drive prosperity and provide complementarity (Bathelt et al., 2004), as well as human capital facilitates the generation and circulation of novel ideas (Romer, 1990; Moretti, 2004). R\&D activities permit the exploration and the transfer of new knowledge, both crucial for innovation; and universities magnify the benefits of proximity (Wallsten, 2001) thus contributing to the local environment by facilitating the creation of new business or attracting firms (Anselin et al., 1997). Spillovers may subsequently influence local labour markets by increasing the demand for specialized skills and by attracting business in search of human capital (Audretsch et al., 2005). Benneworth \& Charles (2005), following Cooke (2005), describes universities as 'knowledge generator subsystems' inside a virtuous circle of global knowledge flowing through the region and out into global markets creating beneficial spillovers for local firms while simultaneously attracting external investment.

Many universities engage with regional partners to provide additional funding sources complementing increasingly scarce public resources. Governments are increasingly promoting university-industry collaboration through a range of subsidised initiatives and infrastructure supporting engagement with nonacademic agents (Klofsten and Jones-Evans, 2000; PACEC, 2009; Abreu and Grinevich, 2013). Universities are placing more priority on their relevance and responsiveness to national, regional and local needs, resulting in a progressive 'institutionalisation' of such interactions (see Charles et al., 2014). Under contemporary conditions of uncertainty, organisations typically develop institutional structures, "regulative, normative, and cognitive structures and activities that provide stability and meaning for social behaviour" (Scott, 1995, p. 33). Despite isomorphic pressures, empirical evidence suggests universities are exhibiting a large heterogeneity both in their degree and form of their entrepreneurial transformation (Jacob et al., 2003; Martinelli et al., 2008; Huyghe and Knockaert, 2014). 
However, at the same time, it has been recently pointed out that this fails to address the contextual heterogeneity in terms of universities' internal capabilities as well as specific regional/local societal needs (Fischer and Varga, 2003; Whitley, 2008; Metcalfe, 2010; Uyarra, 2010). Little consideration is given to the reality of knowledge flows, embedded in complex local relations where universities have multiple parallel contacts and contributions (Power and Malmberg, 2008; Benneworth et al., 2010; Huggins and Williams, 2011).

\subsection{University models based on third mission outputs}

Universities differ in size, status, specialization and focus, both within and across national systems. Different 'types' of universities have historically co-existed within national higher education systems, offering different functions, resources, networks and spatial aspirations (Teichler, 1998; 2004; see also Martin, 2003). These differences mean universities have varying capabilities and expertises for societal engagement: some institutions have always been more tightly integrated as part of their locality throughout their history, interacting with local schools, firms, local authorities and communities (Benneworth, 2014). Conversely, more traditional and prestigious institutions may emphasise their research, teaching and other scholarly activities' national and international orientations rather than local and regional connections ${ }^{1}$.

Within the main recent exploring HEIs' roles in regional development (Goldstein, 2010; Uyarra, 2010), following Trippl et al., 2014, we distinguish two main university models related to the third mission: the Entrepreneurial University (EU) model and the Regional Innovation System University (RISU) model. The emergence of the "entrepreneurial university" (Etzkowitz, 1983; Clark, 1998) acknowledged an important change in universities' structural organization, with new university structures linking academic scientists (the academic heartland) with potential research users via a supportive intermediary environment (Siegel et al., 2007), and their active and strategic importance promoting different

\footnotetext{
${ }^{1}$ But that is not to say that prestigious institutions do not have substantial local and regional impacts and benefits; this is a question of branding not substance. Feldman \& Desrochers (2003) found evidence of the elite Johns Hopkins University creating substantial local spillover benefits even during historical periods where the university had tried to clamp down on these activities as being undesirable.
} 
pathways by which knowledge supports innovation (Uyarra, 2010). In this model, universities contribute to regional prosperity by commercializing their knowledge through spin-offs, patents, and licensing (Trippl et al., 2014; Grimaldi et al., 2011). A strong steering core is necessary (Clark, 1998) to implement new incentive and reward structures for commercialization, create a business-friendly academic culture, and creating supportive internal structures such as technology transfer offices (Goldstein, 2010).

The RISU approach (Cooke, 1992; Cooke et al., 2004) conceptualises universities roles in interactive innovation processes coming both in knowledge production but also in shaping overall organisation and governance of particular regional innovation systems. In this framework, regular interactions between knowledge producers, users, intermediaries and policy makers create networks with systemic properties at the regional scale. HEIs make not exclusively commercialisation based contributions but also help by optimising regional networks and their systemic innovation properties, making important both formal R\&D co-operations alongside informal knowledge transmission not involving financial compensations (Trippl et al., 2014; Olmos-Peñuela et al., 2013). This model distinguishes 'soft' activities (advisory roles, consultancy, industry training, production of highly qualified graduates), closer to the traditional academic paradigm, from 'hard' initiatives such as patenting, licensing and spin-off activities (Philpott et al.; 2011).

Figure 1 summarizes those activities that define and distinguish each university model:

Figure 1. Role of universities in regional development using the economic dimension

\begin{tabular}{|c|c|}
\hline \multicolumn{2}{|c|}{ University model } \\
\hline Entrepreneurial university & $\begin{array}{c}\text { Regional Innovation Systems } \\
\text { University }\end{array}$ \\
\hline $\begin{array}{c}\text { Commercialization } \\
\text { activities: } \\
\text { Patents, licensing, spin-offs }\end{array}$ & $\begin{array}{l}\text { + collaborative \& contract } \\
\text { research, consulting, ad hoc } \\
\text { advice, networking }\end{array}$ \\
\hline & with practitioners \\
\hline
\end{tabular}

Source: Adapted from Trippl et al. (2014) 


\subsection{Linking localised knowledge spillovers to university structural configuration}

We contend that the study of universities' internal configurations is interesting both because it is the one area where university managers may exert control (are able to reinforce academic outputs via the formal institutional structure, as well as being relatively under-researched in the literature (McCormack et al. 2014). There has been an expansion of formalised approaches to third mission activities in recent decades as senior managers have sought to build certainty and control over the extremely uncertain and potentially risky business of transferring knowledge into the external environment (Benneworth, 2007). Specific empirical works have immersed in this debate like Goodall (2009) that explores the role of leaders in UK and USA in universities arguing that strong senior academic leadership is associated with improved university-level research performance. McCormack et al. (2014) analysing 250 UK university departments find evidence that university management matters, particularly with respect to provision of incentives for staff recruitment, retention and promotion.

Different kinds of institutional arrangements within universities may likewise affect universities' societal (including regional) contributions. Siegel et al. (2003) conclude that a faculty reward system and the availability of technology transfer offices are critical organizational factors. Besley and Ghatak (2005) and Bénabou and Tirole (2006) have emphasised that sharp incentives may not be as important or effective where agents are motivated.

Focus on the two universities models described, it is expected that universities develop and reinforce different internal structures in order to adapt themselves to their intrinsic expectations. In the EU model, an extended development periphery (such as a technology transfer offices that support academics in commercialising their activities) seeks to link the university as knowledge producing sub-system to knowledge exploiters, innovating firms. In the RISU model, to engage with other actors and drive other changes with policy-makers, intermediaries and other civil society organisations, there would be a more diversified set of activities 
stimulating and encouraging academics in undertaking both formal and informal engagements.

To operationalise the EU and RISU models, we propose an analysis of university internal structure based on Benneworth et al. (2014). Formalising Clark's (1998) model they argue that internal university structure can be described through four elements:

a) the strategic role played by the central steering core, in articulating a shared vision and strategic platform for engagement;

b) a supportive administrative apparatus, ensuring institutionalization of rules and procedures as well as support/incentive structures across the board;

c) the efforts by, and commitment of, key individuals across the academic heartland, whilst recognizing new external opportunities and directly engaging with external parties; and

d) the degree of coupling between core and peripheral structures and activities, ensuring spill-over effects and mutually reinforcing synergies (Clark, 1998, 2004; Nedeva, 2007; Pinheiro, 2012a, b),

These four elements define an organisational configuration by which universities define missions and organise functions to deliver core activities (see Figure 2).

\section{Figure 2. The University as an Organization}

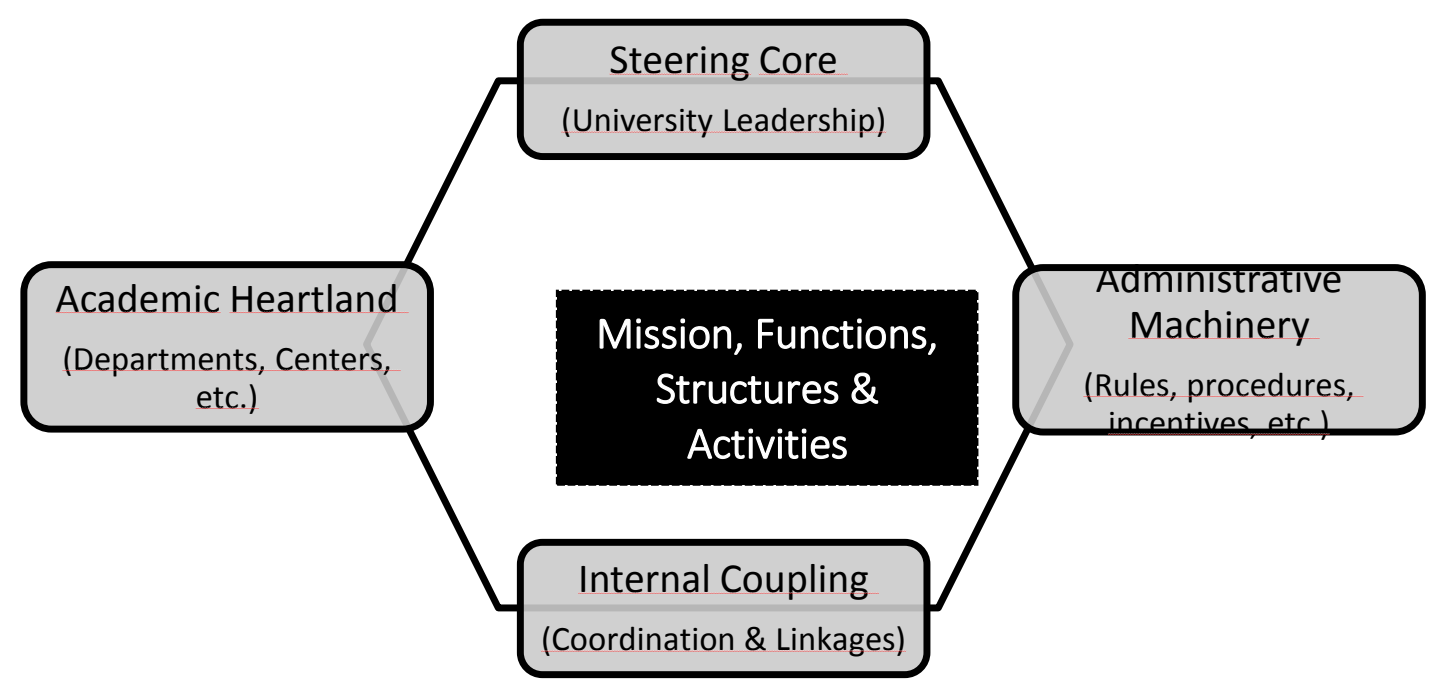

Source: Benneworth et al. (2014) 
We further specify these four university structural elements as follows:

a) Steering core (leadership and strategy): for regional engagement to become a more substantive task within the university, it is necessary for university leaders to change the institution. Central to this is leadership from senior managers, but also the way that institutional entrepreneurs within the university seek to actively promote change and drive regional development. The activities of the steering core will often be articulated in and complemented by strategy and policy documents, as well as statements of mission, vision and strategies and aims.

b) Administrative machinery: universities manage their activities through decision-making apparatuses at a variety of levels from central policy to determining courses and degree outcomes, giving legitimacy and accountability to those decisions. The extent to which universities are able to engage with their regional contexts depends to a degree on how the administrative machinery responds to this challenge, and its amenability to regarding external engagement as a legitimate university activity.

c) Internal coupling: The internal validity of external engagement arises in the ways that it becomes coupled to other activities and is able to derive power legitimacy and resources within the institution. Effective external engagement depends of having mechanisms within the university that couple these external activities to 'core' activities in ways that legitimise them and prevent them remaining peripheral to the central academic enterprise.

d) Academic heartland: For engagement to be effective within the university, then it requires a core group of academics who are actively engaged, who see that engagement as being scientifically legitimate. These engagement academics are also regarded as legitimate within the wider academic structures of the university, including by those academics who are not themselves engaged. 
We use this framework to explore our main research question by providing four dimensions along which universities internal structures might affect the delivery of third mission outputs, focusing specifically on three operational questions:

- Which components of universities' internal structural university affect university regional engagement performance?

- Do EU and RISU models differ? And

- How does university internal strategic structure specifically affect third mission delivery in terms of the regional development?

We argue that individual university institutional configurations affect the production of specific regional impacts, although following Ponds et al. (2010) we do not claim that all knowledge spillover effects are regionally-contained, but rather that a region represents a space where universities' external contributions have a high likelihood of being visible. To explore these three questions, we focus on one element of the process by which universities create regional benefits, specifically on the creation of third mission outputs, and the extent to which internal institutional configuration affects the production of these benefits.

\section{Empirical strategy}

The empirical strategy adopted in this work is based on the UK context where universities have been specifically funded since 1999 in England (and later in the other UK nations) to engage with business and community partners (Benneworth \& Jongbloed, 2013). Universities have sought to actively manage this process to both maximise their benefits from engagement as well as best fitting it into their other core activities. To better contextualise this study, we briefly review UK third mission policy and university characteristics, alongside the data and methodology we use in solving our operational research questions.

\subsection{The context: UK third mission policy in HEIs}

'Third mission' university activities involve generating, using, exploiting and applying knowledge and other university capabilities outside academic environments (Molas-Gallart et al., 2002). Third mission activities have received 
substantial policy and academic attention (Polt et al., 2001; European Commission, 2003). Following the US's 1980 Bayh-Dole Act of 1980 that encouraged university commercialisation and active Intellectual Property Rights (IPR) management (Henderson et al., 1998), similar legislative reforms followed across Europe (Mowery \& Sampat, 2005). The third mission in the UK context involves interactions between HEIs and private, public, voluntary and societal organisations that support knowledge transfer and exchange (HEFCE, 2009).

Policies across UK nationals have embraced commercialisation explicitly as a key target for HEIs performance influencing future government funding levels (PACEC, 2009). Commercialization activities have been further institutionalized and broadened under this agenda, representing what Uyarra (2010) describes as a 'transformation'. This involved the establishment of novel administrative offices/structures (including technology transfer offices -TTOs- and business incubators) to co-ordinate internally and liaise externally, increasing financial resources for technology transfer and promoting different activity mixes.

The connexion between the selected context and the reviewed literature appears because the UK policy can likewise be distinguished into areas targeting EU and RISU measures (Trippl et al., 2014). Some national policy has sought to promote entrepreneurial activities, covering IPR regulations, public subsidies for TTOs, science parks and incubators and directly funding academic spin-off processes. Other policies have focused more on encouraging universities to improve their regional environments, fostering the creation of various types of universityindustry links and integrating universities within regional cluster and innovation strategies (Kitagawa, 2004).

\subsection{Data \& Variables}

The empirical section in this paper draws on the Higher Education Business and Community Interaction Survey (HE-BCI). HE-BCI is an annual survey ${ }^{2}$ administered throughout the UK since a 2001 pilot (Charles \& Conway, 2002) by the Higher Education Funding Council for England (HEFCE). This data is publicly

\footnotetext{
2 The questionnaire is available at: http://www.hesa.ac.uk/index.php?option=com collns\&task=show colln\&Itemid=232\&c=C11031\& $\mathrm{s}=5 \& \mathrm{wvy}=$ any \&wvs $=1$ \&isme $=1$
} 
available and provides information at the level of the individual university about knowledge exchange between universities and the wider world. The data informs the strategic direction of 'knowledge exchange' activity, their capacity and infrastructure in place to deliver this activity, as well as levels of income and activity across a range of metrics on the commercialization of knowledge. The database is structured in two parts. Indicators relating to strategy and infrastructure are collected under Part A of HE-BCI; these tend to be self-assessed responses where HEIs either select from a range of options or benchmark questions which allow respondents to place themselves on a scale of development. This part of the survey provides us information about the internal structure of the university. Part B includes financial and numeric metrics collected related to commercialization and knowledge exchange activities, which is translated as the third mission outputs in our theoretical model. The analysis in this paper draws on the data for the academic year 2011-12 (HEFCE, 2013), because it is the last available information including regional outputs in Part B. All 161 publicly funded UK HEIs provided data for this survey although only 135 (83.9\%) were included in the analysis due to the missing information for some of the variables used here. In terms of the geographical distribution of these HEIs, 80\% are located in England, $11.9 \%$ in Scotland, $6.7 \%$ in Wales and the remainder in Northern Ireland.

Figure 3 shows our theoretical model, representing the four elements of the internal structure of the universities (on the left hand side) and establishes their relationship as explicative factors of university third mission performance measured by EU and RISU activities (on the right hand side) following Tripp et al. (2014) as described in Figure 2. Taking into account that this is an explorative and experimental study, we have sought to use a broad selection of the variables in Part A of HE-BCI survey to describe and configure the four theoretical components of the university structure. However, as the survey was not built using the theoretical model proposed here, the selected variables on the left hand side of Figure 3 are those variables that have been identified as producing the optimum and simplest empirical model for the objective of this research with the highest explicative power. Or in other words, those questions included in part A that theoretically fit to measure the four elements of university internal structure, but 
empirically do not fulfil the requirements to be understood as items measuring the same concept are not presented here. In consequence, the steering core, related to the leadership and strategy of each university, is measured by the availability of a strategic plan at institutional level for business support. Two variables are included to describe the administrative machinery, related to the rules, procedures and incentives that exist at institutional level to impulse knowledge transfer activities and social engagement at regional level: the requirement to report the creation of IPR and the existence of rewards for the IPR generated. Three main variables specify coordination and linkages that make up the internal coupling of the university, all of them related to the existence of internal structures or departments for specific connection mechanisms with non-academic agents: assistance to small and medium enterprises (SMEs), interaction with business and community and searching for IPR opportunities. Finally, academic heartland covers the specificities of individual academics that engage with regional agents at different levels: the community, clients and/or public partners. A detailed explanation of these variables appears in Table 1 . This table also presents the definition of the activities included in the analysis of third mission performance.

Figure 3. Theoretical model

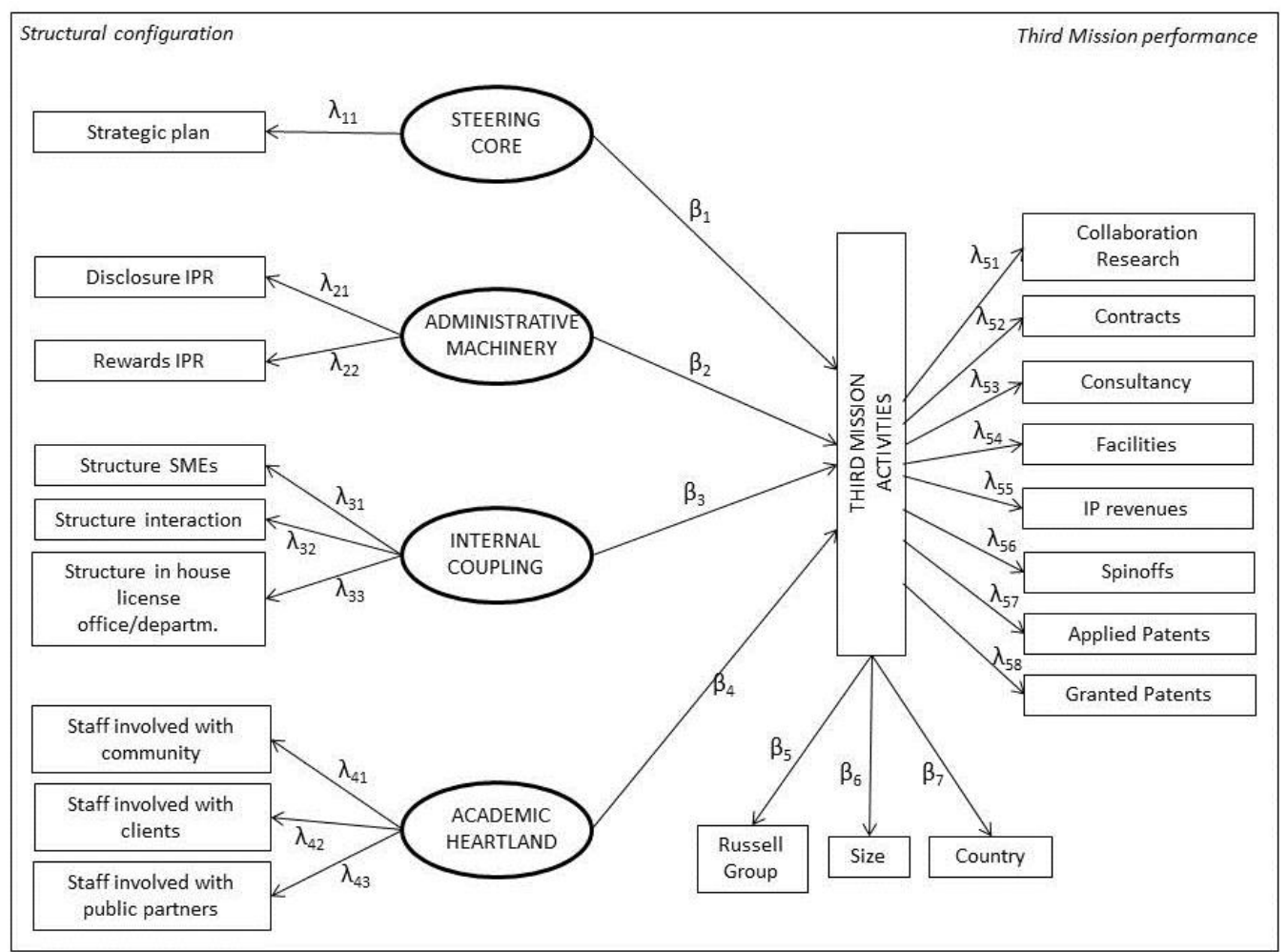




\section{Table 1. Definition of the main variables of the study}

\begin{tabular}{|c|c|c|c|c|c|c|}
\hline \multicolumn{7}{|c|}{ Part A. Structural configuration } \\
\hline Internal conf. & \multirow{2}{*}{\multicolumn{2}{|c|}{$\begin{array}{r}\text { Variable } \\
\text { Strategic plan }\end{array}$}} & Definition (Question number in HE-BCI) & \multicolumn{3}{|c|}{ Type of variable } \\
\hline Steering core & & & $\begin{array}{l}\text { University has a strategic plan totally developed and partially or totally } \\
\text { implemented for business support (Q7a). }\end{array}$ & \multicolumn{3}{|c|}{$\begin{array}{l}\text { Dummy variable with value } 1 \text { if university answered values } \\
4 \text { or } 5 \text { and } 0 \text { otherwise. }\end{array}$} \\
\hline \multirow{2}{*}{$\begin{array}{l}\text { Administrative } \\
\text { machinery }\end{array}$} & \multicolumn{2}{|c|}{ Disclosure IPR } & $\begin{array}{l}\text { There are requirements within the HEI to report or disclose (internally) the } \\
\text { creation of IPR (inventions, software, copyright, design, trademarks, } \\
\text { plant/animal varieties) to the disclosure company or department (Q18) }\end{array}$ & \multicolumn{3}{|c|}{$\begin{array}{l}\text { Dummy variable with value } 1 \text { if university answered 'always' } \\
\text { in at least one of the IPR categories and } 0 \text { otherwise. }\end{array}$} \\
\hline & \multicolumn{2}{|c|}{ Rewards IPR } & University has rewards for staff related to the IPR that they generate (Q19) & \multicolumn{3}{|c|}{$\begin{array}{l}\text { Dummy variable with value } 1 \text { if university answered 'yes' } \\
\text { and } 0 \text { otherwise. }\end{array}$} \\
\hline \multirow{3}{*}{$\begin{array}{l}\text { Internal } \\
\text { coupling }\end{array}$} & \multicolumn{2}{|c|}{ Structure SMEs } & $\begin{array}{l}\text { University has a central dedicated unit that act as an enquiry point for SMEs } \\
\text { or assistance to SMEs in specifying their needs (Q11) }\end{array}$ & \multicolumn{3}{|c|}{$\begin{array}{l}\text { Dummy variable with value } 1 \text { if university answered 'yes' to } \\
\text { the availability of 'An enquiry point for SMEs' or 'Assistance } \\
\text { to SMEs in specifying their needs' in Q11 and } 0 \text { otherwise. }\end{array}$} \\
\hline & \multicolumn{2}{|c|}{$\begin{array}{l}\text { Structure } \\
\text { interaction }\end{array}$} & $\begin{array}{l}\text { University has an internal department responsible for business and } \\
\text { community interactions (Q12) }\end{array}$ & \multicolumn{3}{|c|}{$\begin{array}{l}\text { Dummy variable with value } 1 \text { if university answered 'yes, } \\
\text { internal department' and } 0 \text { otherwise. }\end{array}$} \\
\hline & \multicolumn{2}{|c|}{$\begin{array}{l}\text { Structure in-house } \\
\text { licence } \\
\text { office/department }\end{array}$} & $\begin{array}{l}\text { University has, at least, in-house capability to seek out licensing } \\
\text { opportunities for IPR (patents, copyrights, designs \& trademarks) (Q10) }\end{array}$ & \multicolumn{3}{|c|}{$\begin{array}{l}\text { Dummy variable with value } 1 \text { if university answered 'yes, in- } \\
\text { house capability' or 'yes, in-house capability \& external } \\
\text { agency' and } 0 \text { otherwise. }\end{array}$} \\
\hline \multirow{3}{*}{$\begin{array}{l}\text { Academic } \\
\text { heartland }\end{array}$} & \multicolumn{2}{|c|}{$\begin{array}{l}\text { Staff involved with } \\
\text { community }\end{array}$} & $\begin{array}{l}\text { Percentage of academic staff providing service to social, community and } \\
\text { cultural partners between } 1 \text { August } 2011 \text { \& } 31 \text { July } 2012 \text { (Q15a) }\end{array}$ & \multicolumn{3}{|c|}{ Continuous variable. } \\
\hline & \multicolumn{2}{|c|}{$\begin{array}{l}\text { Staff involved with } \\
\text { clients }\end{array}$} & $\begin{array}{l}\text { Percentage of academic staff providing service to commercial } \\
\text { partners/clients between } 1 \text { August } 2011 \& 31 \text { July } 2012 \text { (Q15b) }\end{array}$ & \multicolumn{3}{|c|}{ Continuous variable. } \\
\hline & \multicolumn{2}{|c|}{$\begin{array}{l}\text { Staff involved with } \\
\text { public partners }\end{array}$} & $\begin{array}{l}\text { Percentage of academic staff providing service to public sector } \\
\text { partners/clients between } 1 \text { August } 2011 \text { \& } 31 \text { July } 2012 \text { (Q15c) }\end{array}$ & \multicolumn{3}{|c|}{ Continuous variable. } \\
\hline \multicolumn{7}{|c|}{ Part B. Third mission activities } \\
\hline \multirow{2}{*}{\multicolumn{2}{|c|}{ Name }} & \multirow{2}{*}{\multicolumn{2}{|c|}{ Definition }} & \multicolumn{3}{|c|}{ University model } \\
\hline & & & & $\begin{array}{l}\text { Model 1: } \\
\quad \text { EU }\end{array}$ & $\begin{array}{l}\text { Model 2: } \\
\text { RISU }\end{array}$ & $\begin{array}{c}\text { Model 3: } \\
\text { RISU (simplified) } \\
\text { with regional outputs }\end{array}$ \\
\hline \multicolumn{2}{|c|}{ Collaboration Research } & \multicolumn{2}{|c|}{ Total income from collaborative research involving public funding in current year ( $€ 000 \mathrm{~s}$ ) } & & $\mathrm{X}$ & \\
\hline \multicolumn{2}{|l|}{ Contracts } & \multicolumn{2}{|c|}{ Total income of contract research (excluding collaborative research) in current year ( $£ 000 \mathrm{~s})$} & & $\mathrm{X}$ & $\mathrm{X}$ \\
\hline \multicolumn{2}{|l|}{ Consultancy } & \multicolumn{2}{|c|}{ Total income in consultancy contracts in current year $(£ 000 \mathrm{~s})$} & & $\mathrm{X}$ & $\mathrm{X}$ \\
\hline \multicolumn{2}{|l|}{ Facilities } & \multicolumn{2}{|c|}{ Total income in facilities \& equipment in current year $(£ 000 \mathrm{~s})$} & & $\mathrm{X}$ & $\mathrm{X}$ \\
\hline IP Revenues & & Total income & in IP revenues in current year $(£ 000 \mathrm{~s})$ & $\mathrm{X}$ & $\mathrm{X}$ & $\mathrm{X}$ \\
\hline Spinoffs & & Number of $\mathrm{sl}$ & n-offs with some HEI ownership in current year & $\mathrm{X}$ & $\mathrm{X}$ & \\
\hline Applied patents & & Number of $n$ & w patent applications filed in current year & $\mathrm{X}$ & $\mathrm{X}$ & \\
\hline Granted Patents & & Number of $\mathrm{p}$ & tents granted in current year & $\mathrm{X}$ & $\mathrm{X}$ & \\
\hline
\end{tabular}


The theoretical model described in Figure 3 also includes three variables that act as controls. First, it is important to control for those universities member of the Russell Group because they are a self-selecting group seeking to differentiate themselves from other universities in the sector (Russell Group, e.g. press release dated $21^{\text {st }}$ November $2014^{3}$ ). As research-oriented universities, their third mission activities can be influenced due to a positive relationship between research and third mission activities (SánchezBarrioluengo, 2014). We account for this by including a dummy variable to differentiate Russell Group (RG) universities from non RG-members. Secondly, it is important to take into account the size of the universities given the heterogeneity within the university sector (Hewitt-Dundas, 2012). This control variable includes number of total staff working in each university. Thirdly, taking into account that higher education policies differ significantly between UK nations (England, Scotland, Wales and Northern Ireland: Scott, 2013) including the instruments and incentives for third mission (Huggins and Kitagawa, 2011; Kitagawa and Lightowler, 2013), the third control is a dummy variable with the value 1 if the university is located in England and 0 otherwise. To avoid biased results due to different unit of measurement of the variables, all variables have been normalized except the dummy controls. ${ }^{4}$

\subsection{Methodology}

The empirical section includes two steps: first, a factor analysis, including varimax rotation and Kaiser normalization, (Hair et al., 1998) to check if the selected measures group together to describe the university's structural configuration. Second, the theoretical model presented in Figure 3 is empirically tackled using the structural equation modelling (SEM) as methodology and represents the path diagram (Wright, 1934). The advantage of this methodology is the possibility of measuring abstract concepts (constructs or latent variables), using them as independent variables in a subsequent regression model. The analysis involves three steps: first, model specification, where the parameters to be estimated are the (a) regression coefficients, and (b) the variances and the covariances of the independent variables in the model

\footnotetext{
${ }^{3}$ http://www.russellgroup.ac.uk/russell-group-latest-news/155-2014/8585-russell-group-sign-leidenstatement-on-the-social-sciences-and-humanities/ (Accessed 21 November 2014)

${ }^{4}$ The study includes two types of variables. Measures of university's structural configuration are dummies while third mission activities are continuous variables. The normalization process has been as follows: dummy variables are normalized by subtracting the mean of the variable; continuous variables are normalized by subtracting the means and dividing by its standard deviation.
} 
(Bentler, 2004). Second, model estimation, is based on the covariance matrix and an iterative procedure that finds the values of the equation that minimize discrepancies between the data and the theoretical model proposed in the first step (Lee, 2007). Following Olsson et al. (2000), we use maximum likelihood to solve the iterative procedure because is a more robust procedure (compared to Generalized Least Squares). In addition, for the model estimation we use the marker variable method of scaling, that means, fix to 1 the variances of the latent variables and give free the parameters to be estimated (Little, 2013). The third step is model evaluation. The model test statistic has a chi-square distribution if it is correctly specified, and can be used to test the null hypothesis that the theoretical model fits the data. Since the chi-square coefficient has been found to be extremely sensitive to sample size, a set of complementary indices are created (Batista-Foguet and Coenders-Gallart, 2000). We use three incremental fit indices - NNFI, CFI and RMSEA ${ }^{5}$ to evaluate the model. One common rule-of-thumb for implementing SEM is that it should have a minimum threshold of 100 subjects (Williams et al., 2004); our population is above this threshold.

We run the SEM equations for three different models. Model 1 includes third mission activities in the EU model (IP revenues, spinoffs, applied patents and granted patents). Model 2 includes, in addition to the above, collaboration research, contracts, consultancy and facilities configuring the RISU model. Finally we have applied SEM including as third mission activities specific regional output variables as a particular case of the RISU model $^{6}$ (Model 3). Right-bottom part of Table 1 specifies the activities included in each model.

\section{Results}

Results presented here are divided in two sections. The first section describes the suitability of the selected variables to measure university's structural configuration. The second section presents the main empirical results for the SEM applied to the three

\footnotetext{
${ }^{5}$ Non-Normed Fit Index (NNFI), Comparative Fit Index (CFI), and Root Mean Square Error of Approximation (RMSEA). For more information see Batista-Foguet and Coenders-Gallart (2000).

${ }^{6}$ Unfortunately HE-BCI survey only includes regional information for contracts, consultancy, facilities and IP revenues among the selected activities.
} 
university models described. Before them, Table 2 presents the descriptive statistics of the variables used in this study.

Table 2. Descriptive statistics

\begin{tabular}{|c|c|c|c|c|}
\hline \multicolumn{5}{|l|}{ Dummy variables } \\
\hline Strategic plan & \multicolumn{4}{|c|}{$85.9 \%$} \\
\hline Disclosure IPR & \multicolumn{4}{|c|}{$88.9 \%$} \\
\hline Rewards IPR & \multicolumn{4}{|c|}{$81.5 \%$} \\
\hline Structure SMEs & \multicolumn{4}{|c|}{$77.8 \%$} \\
\hline Structure interaction & \multicolumn{4}{|c|}{$94.1 \%$} \\
\hline $\begin{array}{l}\text { Structure inhouse licensce } \\
\text { office/department }\end{array}$ & \multicolumn{4}{|c|}{$86.7 \%$} \\
\hline Control: Russell Group & \multicolumn{4}{|c|}{$17.8 \%$} \\
\hline Control: Country & \multicolumn{4}{|c|}{ England: $80 \%$} \\
\hline \multicolumn{5}{|l|}{ Continuous variables } \\
\hline & Mean & S.D. & Min. & Max. \\
\hline Staff involved with community (\%) & 16.7 & 13.3 & 0 & 65 \\
\hline Staff involved with clients (\%) & 18.7 & 14.2 & 0 & 75 \\
\hline Staff involved with public partners (\%) & 22.6 & 15.5 & 0 & 80 \\
\hline Collaboration Research $(£ 000 \mathrm{~s})$ & 96.4 & 205.5 & 0 & 995 \\
\hline Contracts $(£ 000 \mathrm{~s})$ & 157.9 & 271.4 & 0 & 952 \\
\hline Consultancy (£000s) & 148.8 & 231.1 & 0 & 987 \\
\hline Facilities (£000s) & 144.8 & 234.8 & 0 & 908 \\
\hline IP Revenues (£000s) & 111.1 & 214.4 & 0 & 847 \\
\hline Spinoffs & 1.11 & 1.9 & 0 & 12 \\
\hline Applied patents & 16.7 & 36.4 & 0 & 298 \\
\hline Granted Patents & 6.0 & 17.7 & 0 & 175 \\
\hline Control: Size & $2,307.27$ & $1,995.14$ & 88 & 10,523 \\
\hline
\end{tabular}

Descriptive results show that $86 \%$ of the UK HEIs has developed a strategic plan implemented for business support. Similar proportions of universities include incentives for the creation of IPR as well as in those institutions where researchers should disclosure the IPR they generate. More than $90 \%$ of the universities include formal offices/departments to facilitate interaction with external agents, while only $78 \%$ are specific to establish relationships with small and medium firms (SMEs). Commercialization appears at the core of universities activities guided by the conversion of patents into licences through the in-house license office/department that exists in $87 \%$ of the institutions. In terms of the staff providing service to external agents, researchers are highly engaged because more than $65 \%$ of the staff working at the universities is involved with different types of partners. On the other hand, university third mission outputs occur mainly by contracts, consultancy and facility activities. Income in form of revenues is relegated to a secondary position, which is in line with the research of other authors that reported that contract research and consultancy are the most frequent interactions between universities and firms (D'Este and Patel, 2007) with patenting and licensing of relatively lower importance (Cohen et al., 2002). Universities 
have created 1.11 spinoffs on average, applied for 16.7 patents while only 6 patents on average are granted within the UK HE sector.

\subsection{Measuring university structural configuration}

Table 2 includes the results from factor analysis. In this case the criteria to select the number of factors to extract is the percentage of variance explained: what is not uncommon in social science studies is to consider a solution with $60 \%$ of the total variance as satisfactory (Hair et al., 1998). As previously explained, the selected variables result in the optimum model to explain university's internal structural and corroborate their grouping as descriptors of the four dimensions of structural configuration. Although we have calculated the Cronbach's alpha as a measure of the reliability of each construct, their values are rather low because this coefficient is a direct function of the number of items explaining the construct (and there are at most three components considered in each item). To compensate for the weakness of this test, we have included in the next section three incremental fit indices as a complement to check reliability.

Table 3. Results of factor analysis: measures of university's structural configuration

\begin{tabular}{|c|c|c|c|}
\hline & & Communalities & Item Score \\
\hline \multirow{4}{*}{ Steering core } & Strategic plan & 0.694 & 0.750 \\
\hline & Explained variance & \multicolumn{2}{|l|}{9.27} \\
\hline & Eigenvalue & \multicolumn{2}{|c|}{0.834} \\
\hline & Chronbach's alpha & \multicolumn{2}{|l|}{-} \\
\hline \multirow{5}{*}{$\begin{array}{c}\text { Administrative } \\
\text { machinery }\end{array}$} & Disclosure IPR & 0.656 & 0.879 \\
\hline & Rewards IPR & 0.777 & 0.572 \\
\hline & Explained variance & \multicolumn{2}{|c|}{13.67} \\
\hline & Eigenvalue & \multicolumn{2}{|c|}{1.231} \\
\hline & Chronbach's alpha & \multicolumn{2}{|c|}{0.473} \\
\hline \multirow{6}{*}{$\begin{array}{l}\text { Internal } \\
\text { coupling }\end{array}$} & Structure SMEs & 0.623 & 0.747 \\
\hline & Structure interaction & 0.566 & 0.618 \\
\hline & $\begin{array}{l}\text { Structure inhouse licensce } \\
\text { office/department }\end{array}$ & 0.570 & 0.606 \\
\hline & Explained variance & \multicolumn{2}{|c|}{26.53} \\
\hline & Eigenvalue & \multicolumn{2}{|c|}{2.387} \\
\hline & Chronbach's alpha & \multicolumn{2}{|c|}{0.542} \\
\hline \multirow{6}{*}{$\begin{array}{l}\text { Academic } \\
\text { heartland }\end{array}$} & Staff involved with community & 0.794 & 0.878 \\
\hline & Staff involved with clients & 0.784 & $0.399^{a}$ \\
\hline & Staff involved with public partners & 0.734 & 0.827 \\
\hline & Explained variance & \multicolumn{2}{|c|}{19.41} \\
\hline & Eigenvalue & \multicolumn{2}{|c|}{1.747} \\
\hline & Chronbach's alpha & \multicolumn{2}{|c|}{0.402} \\
\hline
\end{tabular}

Note: Total variance explained: $68.88 \%$. "The variable "staff involved with clients" presents a value of 0.660 as an item score in the same component as "strategic plan", however there is not an easy theoretical justification for this fact and for this 
reason we have included the variable in the group of "Academic heartland" where the variable presents the second highest item score.

\subsection{The effect of structural configuration on third mission performance across university models}

Before starting the analysis of results we check the evaluation tests of the models (Table 3 ). The goodness of fit is determined mainly by the $\chi^{2}$ statistic but, as in the previous case, this coefficient is a direct function of the number of items used. In addition, the three incremental fit indices - NNFI, CFI and RMSEA - confirm the model's goodness of fit: the values of the first two indices are above 0.95 , and the last presents a small value. These results confirm the importance of the selected indicators for measuring university's structural configuration and third mission performance as well as the relationship between both of them.

In terms of empirical results, all the variables selected to measure the structural dimensions of each university present a positive and significant value of the coefficient ( $\lambda_{\mathrm{ij}}$ where $\left.\mathrm{i}=1, . ., 4\right)$, which can be interpreted as the adequacy and robustness of these items to capture the content of each internal structure element. It is important to note that the entrepreneurial model (Model 1) is able to capture the inadequacy of specific structure for SMEs and interactions, an activity much more specific of the RISU model (Model 2 and 3). However, results for the measurement of third mission construct present a slight difference $\left(\lambda_{5 \mathrm{j}}\right)$. The EU is mainly described by spinoff and patent activities, specifically the latter, and not by IPR revenues. In the case of Model 2, the inclusion of collaboration research, contracts, consultancy and facilities looks like not enough to categorize this kind of institutions because these 'soft' activities present nonsignificant and even negative results. The RISU model description is complete when the combination activity-actor is taken into account. This means that the RISU model description is well-understood when account for the above mentioned activities at regional level (Model 3).

Finally, central part of Table 4 shows the relationship between the four dimensions of internal university structure and the third mission performance. Although not all results are significant, the signs of the coefficients give us an idea about the relative importance of this constructs in university outputs. Firstly, steering core and administrative machinery tend to have a positive influence in entrepreneurial outputs, while specific 
internal coupling is the dimension that presents the highest negative effect, being the unique significant result. Model 2 (RISU) shares the sign of the coefficients with Model 1, although we should be cautious with the interpretation of these results due to the limitation explained before. Finally, Model 3 (RISU simplified) shows that only academic heartland presents a negative value of the coefficient although not significant, while the rest, steering core, administrative machinery and internal coupling tend to increase regional outputs. In this case those indicators related to IPR disclosure and rewards are the most important shapers of the RISU model.

Table 4. SEM results for the three university models described ${ }^{a}$

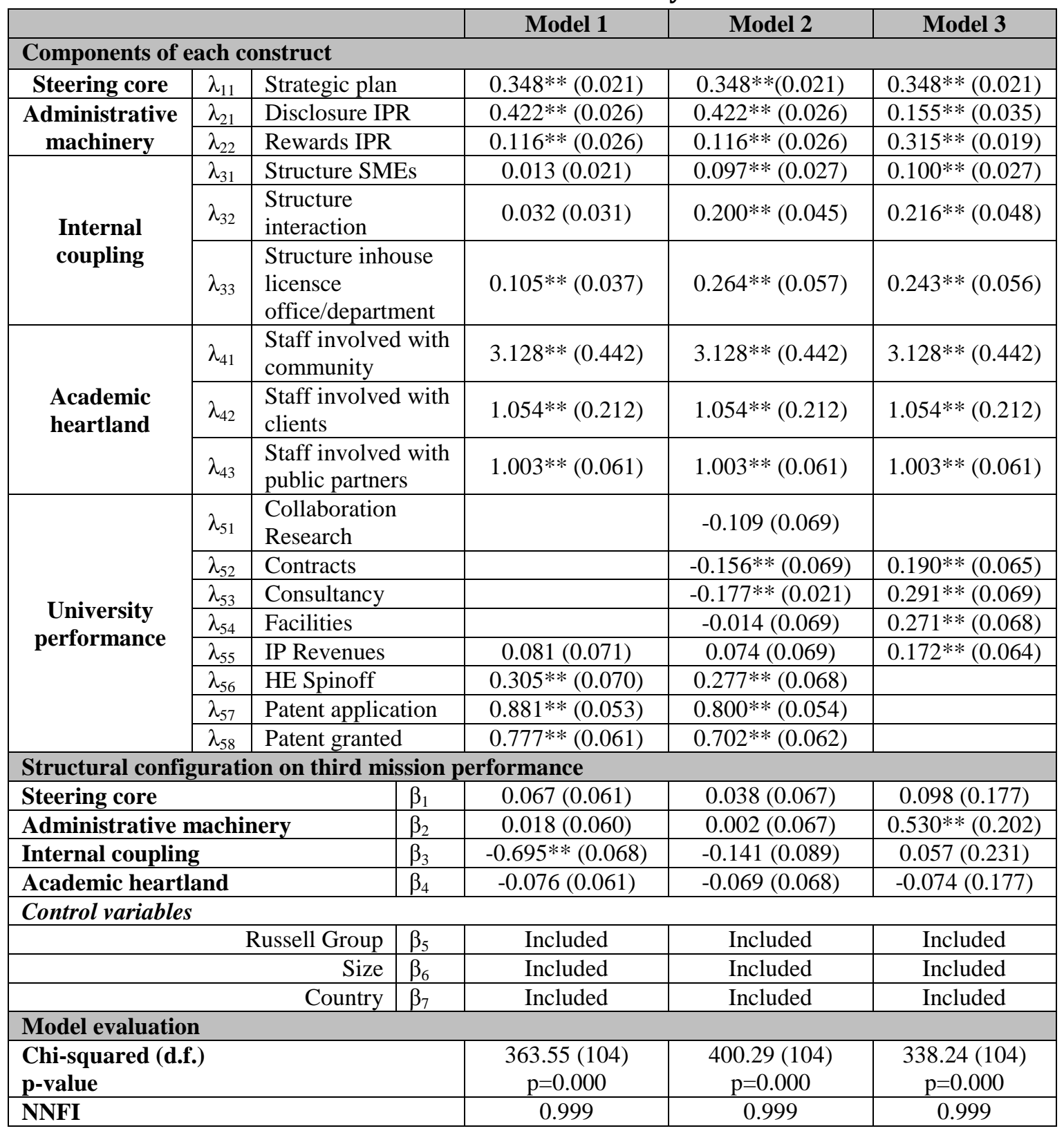




\begin{tabular}{|l|c|c|c|}
\hline CFI & 0.999 & 0.999 & 0.999 \\
\hline RMSEA & 0.136 & 0.101 & 0.130 \\
\hline
\end{tabular}

Note: ${ }^{* *}$-value $<0.05$. a Parameters estimated, standard deviation between brackets. 


\section{Universities contributions to regional upgrading processes}

Our results suggest that our approach to measure the university internal structure in terms of its effects on regional engagement behaviour have some substance. In particular, the steering core, the administrative apparatus, the academic heartland and the internal coupling appears capture respectively the leadership, rules and procedures, agents and coordination and linkages that constitute the basis of the internal structure. Although the HE-BCI dataset was not specifically designed to explain universities structure, the selected measures presented in this paper appear to be reasonably good proxies to identify the configuration elements, being the internal coupling construct that one further explaining the diversity of university's structures (with 26.53of the variance explained). In this result we see echoes in the institutional literature theory that highlights the importance of formal "factors" that in reality correspond to a university's organizational units explicitly responsible for promoting technology transfer (Dill, 1995) and intensifying its focus on turning their proprietary technology into economic opportunities (Siegel et al., 2003). Thus, our first contention is that our research corroborates the notion that internal coupling is an important structure to consider in the analysis of the internal organization of HEIs.

However, at the same time our research highlights the difference between the EU and the RISU model made by the formal structures within the internal coupling. While the EU model is characterized only by the in-house license office/department, the RISU model combines them also with other intermediary structures, such as those supporting interaction with business and community, to facilitate and guarantee the successful transfer of technology to industry (Link et al., 2003; Siegel et al., 2004). The second model corresponds to a much broader perspective on regional impact, not only through directly stimulating innovation in the innovation system core but also improving the overall functioning of that system via changing policies, intermediaries and culture (Gunasekara, 2006; Lundvall, 2007).

It is also interesting to reflect on university modes of behaviour corresponding to the two models respectively. In the EU, the focus lies on development patents as its main 
output, while spin-offs and IP revenues are not so important results. What has made it popular as a model for universities has been the explosion globally of the idea of patenting as a potentially lucrative income stream. The change came from America in the 1970s, and formalised by the 1980 Bayh-Dole Act in USA (Berman, 2011). As a result of Bayh-Dole, the number of U.S. universities that engage in technology transfer and licensing increased eightfold and the volume of university patents fourfold (Mowery and Shane, 2002). It is not so much that universities themselves have followed the model, but there has been a very strong policy discourse, for example around the OECD (OECD, 2004), which has emphasised the importance of patents as a channel for how universities create their economic impact.

Universities following the RISU model have other exchange activities to go beyond the commercialisation of research and IPR protection which can be less visible, but equally or even more important (D'Este and Patel, 2007). RISU model is more oriented towards collaborative research, contract research or consulting activities, outputs considered by some authors to be more "soft" activities closer to traditional academic activities, compared to 'hard' commercial activities clearly outside the academic realm such as patenting, licensing and spin-off activities (Philpott et al.; 2011). However, reflecting an increasing acknowledgement of the importance of localised knowledge spillovers (Audretsch et al., 2005), there has been an increasing policy drive to encourage universities to facilitate knowledge exchange in their regions. This has been particularly evident in the emergence of new kinds of regional policies and institutions such as regional development agencies and other intermediaries (Uyarra, 2010).

The last results presented in this paper refer to the question about how does university internal strategic structure specifically affect third mission delivery in terms of the regional development and constitutes the more interesting results of this work. It is an exploratory analysis and the first trial to analyse the extant situation and although is clearly limited in terms of significance, it becomes possible to understand what kinds of internal structural are more important for the performance of each university model. Our results suggest that both steering core and administrative machinery influence both EU and RISU models, being the latest specifically relevant at regional level because it presents the unique significant result. Unlike the results in Model 1 and Model 2, at regional level the most influential administrative machinery item is "rewards related to 
IPR". This suggests that under this approach universities magnifying the benefits of proximity (Wallsten, 2001); the easiest way of researchers to obtain rewards under such circumstances being involved in engagement activities with the closest agents. In this respect, authors like Hewitt-Dundas (2012) has found that in the UK, the type and intensity of knowledge transfer is determined by university research quality (see also Laursen et al., 2011), but interactions also differ across partner types, namely SMEs, large firms or non-commercial organisations. Whereas large companies tend to be more attracted to work with a university because of its research reputation in a particular area of interest, small firms may demand more routine services and consultancy, which as less specialised services are more easily found in their local university whatever its overall research profile (Siegel et al., 2007; Pinto et al., 2013).

Lastly, our results also suggest that increasing numbers of researchers ('academic heartland') involved in academic engagement does not necessarily correspond to increased regional performance under either the EU or RISU model. This can be interpreted as a contradiction because intuitively more people active in an area should lead to more outputs, an assumption on this occasion not borne out by the empirical results. Our interpretation here is that engagement activities have become a policy category, and so numbers increase then more people are describing themselves as doing the activity without it necessarily being important to the core university knowledge processes with which they are engaged. We could stylise this as being that researchers are seeking to improve their CVs without necessarily changing their behaviours, corresponding with results elsewhere that there is no simple trade-off between technology transfer and traditional academic activities exists (Uyarra, 2010; Rafferty, 2008). For engagement to be successful, then staff involved at different levels with nonacademic agents do need to have a 'mission', there needs to be some kind of strategic oversight and it needs to be fit for purpose.

\section{University structure as a determinant of societal engagement}

This paper has focused in analysing the role played by the internal university structure as shaper of university performance through third mission activities. Our starting point 
has been an increasing interest within universities and HEIs in balancing between maximizing their specific regional contribution and combining it with the traditional missions of teaching and research. We interpret this as a specifically strategic question namely that is what are the correct strategic choices to maximise the institutional outputs. Consequently, in this paper we have focused on that area of the university that is most amenable to managerial input and control, namely the formal institutional structure (McCormack et al., 2014). But what are the elements of the internal structure that make the difference in both models of what constitute a university creasing impact, namely the EU and RISU models? To do this we offer a preliminary study contributing empirically to Clark's model (1998) formalized in Benneworth et al.'s (2014) work.

In the EU model internal coupling is specifically negatively influencing, a surprising result given that only the in-house license office/department is a component of this construct under this model. Its surprising nature is due to the importance highlighted in the literature of intermediary mechanisms as the TTOs in overcoming communication barriers and effectively link academic scientist and those who could potentially commercialise research (Siegel et al., 2007). While policy makers and university managers are often quite optimistic about the impact of TTOs in fostering technology transfer into the region, some studies do indeed offer evidence that their activities are superfluous and counterproductive (Hülsbeck et al., 2013). Our result can be interpreted as a trade-off of the activities in these offices: are they really influencing patents, spinoffs and IPR revenues (as suggested by the entrepreneurial university discourse) or are they becoming in managerial departments? This question cannot be solved with the available information in this paper, but will be an interesting starting point for future analysis. Although the result is not significant, the internal coupling is only positively influencing third mission outputs at regional level, reinforcing again the importance of proximity as explained before.

While geographical proximity has indeed been found to influence the likelihood of university-industry interaction (Laursen et al., 2011), the spatial dimension of these relations is far from simple and uniform (D'Este and Iammarino, 2010). In this respect, our results suggest that those 'soft' activities analysed present a regional behaviour and a locally orientation because they can only be understood as important part of the RISU model when only regional activities are taken into account. Unlike the work presented 
by Landry et al. (2010) who found that there is a complementary effect between consulting activities and other commercialization outputs like patents and spin-offs, our results are not able to validate the positive relationship between these activities without the consideration of the geographical level. Future analysis should develop specific surveys to analyse if exists this complementarity between 'hard' and 'soft' activities the difference between the EU and the RISU model at the regional level within the UK higher education sector.

It is not our contention that these two models are ideal types for universities to be followed, rather they represent two clearly distinct ways that universities may choose to make their regional contribution, either immediately to firm innovation or by improving the wider regional environment. Because of the exploratory and ex post nature of our study, the proxies we use can at best be interpreted to say that firstly that structure does appear to matter in terms of regional benefit for universities, and secondly, that the way of distinguishing international structure seems to correspond to some degree with the determining processes shaping that impact. There therefore appears to be a prima facie case for attempting to determine a more systematic typology of model university structural configurations for stimulating regional engagement.

Clearly, there are many different kinds of models of university societal engagement in the literature; the entrepreneurial university is just one model, and the civic university (Goddard \& Vallence, 2013), the engaged university (Watson, 2007), and the Virtual University (Delanty, 2002) have all emerged in the higher education studies literature. Exploring these different models, who envisage the university creating impact far beyond the economic realm, is far beyond the possibility of the any analysis involving the HE-BCI database. But given that generating impact seems to be an increasingly urgent policy pressure, and there appear to be many models for achieving it, and our finding that institutional structure makes a different, this raises an important future research question. 


\section{Bibliography}

Abreu, M. and Grinevich, V. (2013). "The nature of academic entrepreneurship in the UK: Widening the focus on entrepreneurial activities". Research Policy, 42(2): 408-422.

Anselin, L.; Varga, A. and Acs, Z. (1997). "Local Geographic Spillovers between University Research and High Technology Innovations". Journal of Urban Economics, 42: 422-448.

Audretsch, D., and Keilbach, M. (2004). "Entrepreneurship capital and economic performance". Regional studies, 38(8): 949-959.

Audretsch, D. and Feldman, M. (2003). "Knowledge Spillovers and the Geography of Innovation" In: Vernon-Henderson, J. and Thisse, J.F. (editors) Handbook of Urban and Regional Economics, Volume 4: 2713-2739.

Audretsch, D.; Lehmann, E.E. and Warning, S. (2005). “University spillovers and new firm location". Research Policy, 34: 1113-1122.

Bathelt, H., A. Malmberg and P. Maskell (2004), "Clusters and Knowledge: Local Buzz, Global Pipelines and the Process of Knowledge Creation". Progress in Human Geography, 28: 31-56.

Batista-Foguet, J. M. and Coenders-Gallart, G. (2000). Modelos de Ecuaciones Estructurales. La Muralla S.A. Madrid.

Benneworth, P. S. (2007) "Seven samurai opening the ivory tower? University commercialisation communities of practise promoting economic development in less successful regions" European Planning Studies, 15(4):487-509.

Benneworth, P. (2014) "Decoding university ideals by reading campuses" in P. Temple (ed.) The physical university. London: Routledge.

Benneworth, P. S. and Charles, D. R. (2005) "University spin off companies and the territorial knowledge pool: building regional innovation competencies?" European Planning Studies, 13 (4): 537-557.

Benneworth, P. and Jongbloed, B. (2013). "Policies for Promoting University-Community Engagement in Practice" in P. Benneworth (ed.) University engagement with socially excluded communities. Dordrecht, Springer

Benneworth, P. S., Pinheiro, R. and Karlsen, J. (2014) The role of the 'Rector' in place based leadership. Paper presented to CHEPS internal seminar, Enschede, the Netherlands, 16th April 2014. Available online at: http://doc.utwente.nl/94142/ (Accessed 17th February 2015).

Benneworth, P. Charles, D., Hodgson, C. and Humphrey, L. (2013). "The Relationship of Community Engagement with Universities' Core Missions" in P. Benneworth (ed.) University engagement with socially excluded communities. Dordrecht, Springer.

Benneworth, P.; Charles, D. and Madanipour, A. (2010). "Building Localized Interactions Between Universities and Cities Through University Spatial Development." European Planning Studies, 18 (10): 1611-1629.

Bentler, P. M. (2004). EQS 6 Structural Equations Program Manual. Encino, CA: Multivariate Software, Inc.

Bénabou, Roland, and Jean Tirole. 2006. "Incentives and Prosocial Behavior." American Economic Review, 96(5): 1652-1678.

Berman, E. (2011). Creating the market university: How academic science became an economic engine. New Jersey: Princeton University Press

Besley, T. and Ghatak, M. (2005). "Competition and Incentives with Motivated Agents." American Economic Review, 95(3): 616-636.

Capello, R., and Nijkamp, P. (2010). Handbook of regional growth and development theories. Edward Elgar Publishing.

Centre for Educational research and innovation (1982). The university and the community: the problems of changing relationships. Paris: OECD-CERI

Charles, D. R. (2011) "The role of universities in building knowledge cities in Australia". Built Environment, 37: 281-298.

Charles, D. R. \& Benneworth, P. S. (2001). The regional contribution of higher education. London: HEFCE/ Universities UK. 
Charles, D.R. and Conway, C. (2002). Higher Education Business Interaction Survey. HEFCE, Bristol.

Charles, D., Kitagawa, F. and Uyarra, E. (2014) "Universities in Crisis? -New Challenges and Strategies in Two English City-regions". Cambridge Journal of Regions, Economy and Society, 7 (2): 327-348.

Clark, B.R (1998). Creating the Entrepreneurial University. Oxford: IAU Press/Pergammon.

Cohen, W. M., and Klepper, S. (1991). Firm size versus diversity in the achievement of technological advance. In Acs Z.J. and Audretsch D.B. (eds) Innovation and technological change: An international comparison. University of Michigan Press, pp. 183-203.

Cohen, W. M., and Klepper, S. (1992). "The tradeoff between firm size and diversity in the pursuit of technological progress". Small Business Economics, 4(1): 1-14.

Cohen, W.M.; Nelson, R.R. and Walsh, J.P. (2002). "Link and impacts: the influence of public research on industrial R\&D." Management Science, 48 (1): 1-23.

Cooke, P. (1992). "Regional Innovation Systems: Comparative Regulation in the New Europe". Geoforum, 23: 365-382.

Cooke, P., Heidenreich, M. and Braczyk, H.J. (2004). Regional innovation systems. 2nd ed. London and New York: Routledge.

Cooke, P. (2005) "Regionally asymmetric knowledge capabilities and open innovation: exploring 'Globalisation 2' - a new model of industry organisation". Research Policy, 34: 1128-1149

Committee of Vice Chancellors and Principals (1994). Universities and Their Communities. London: CVCP, 1994

Cremonini, L.; Westerheijden, D.; Benneworth, P. and Dauncey, H. (2013). "In the Shadow of Celebrity?, World-Class University Policies and Public Value in Higher Education" Higher Education Policy, Advance online publication, October 15, 2013. doi:10.1057/hep.2013.33

De Boer, H.F.; Jürgen E.; and Liudvika L. (2007) "Public sector reform in Dutch higher education: The organizational transformation of the university." Public Administration, 85(1): 27-46.

D'Este, P. and Patel, P. (2007). "University-industry linkages in the UK: What are the factors underlying the variety of interactions with industry?". Research Policy, 36: 1295-1313.

D’Este, P. and Iammarino, S. (2010). "The spatial profile of university-business research partnerships". Papers in regional science, 89: 335.

Delanty, G. (2002) 'The university and modernity: a history of the present'. In Robins, K. and Webster, F. (eds) The Virtual University: Knowledge, Markets and Management. OUP, Oxford.

Dill, D. (1995). "University-industry entrepreneurship: the organization and management of American university technology transfer units". Higher Education, 29: 369-384.

Drucker, J. and Goldstein, H. (2007) "Assessing the Regional Economic Development Impacts of Universities: A Review of Current Approaches” International Regional Science Review, 30(1): 20-46.

Etzkowitz, H. (1983). "Entrepreneurial scientists and entrepreneurial universities in American academic science". Minerva, 21: 198-233.

European Commission (2003). Thematic Trend Report: Industry-Science Relations. Brussels: European Commission

Feldman, M. and Desrochers, P. (2003). "Research universities and local economic development: lessons from the history of Johns Hopkins University". Industry and Innovation, 10(1): 5-24.

Fischer, M.M. and Varga, A. (2003). "Spatial knowledge spillovers and university research: Evidence from Austria." The Annals of Regional Science, 37 (2): 303-322.

Goddard, J. B. (2011) Conencting universities to practical growth: a regional guide. IPTS JRC, Sevilla: Spain Available online at http://ec.europa.eu/regional policy/sources/docgener/presenta/universities2011/universi ties2011 en.pdf

Goddard, J. and Vallance, P. (2013). The university and the city. London: Routledge. 
Goldstein, H. (2010) "The 'entrepreneurial turn' and regional economic development mission of universities". Annals of Regional Science, 44: 83-109.

Goodall, A.H. (2009) "Highly cited leaders and the performance of research universities". Research Policy, 38: 1079-1092

Grimaldi R, Kenney M, Siegel D, et al. (2011) “30 years after Bayh-Dole: Reassessing academic entrepreneurship". Research Policy, 40: 1045-1057.

Gunasekara, C. (2006). "The generative and developmental roles of universities in regional innovation systems". Science and Public Policy, 33(2), 137-150. doi: $10.3152 / 147154306781779118$

Hair, J.; Anderson, R.; Tatham, R. and Black, W. (1998). Multivariate data analysis (5 ${ }^{\text {th }}$ Edition). Prentice Hall.New Jersey.

Healy, A., Perkmann, M., Goddard, J. \& Kempton, L. (2014) Measuring the impact of universitybusiness cooperation. Final report to the Directorate General for Education and Culture, Brussels: DG EAC.

HEFCE (2009). Evaluation of the effectiveness and role of HEFCE/OSI third stream funding: Report to HEFCE by PACEC and the Centre for Business Research. University of Cambridge. Available at: http://www.hefce.ac.uk/pubs/year/2009/200915/

HEFCE (2013). Report on survey Higher Education - Business and Community Interaction Survey 2011-12. HEFCE May 2013/11. Available at: http://www.hefce.ac.uk/pubs/year/2013/201311/\#d.en.81914

Henderson, R., Jaffe, A. B. \& Trajtenberg, M. (1998) "Universities as a source of commercial technology: A detailed analysis of university patenting". Review of Economics \& Statistics, 80(1), pp. 119-127.

Hewitt-Dundas, N. (2012) "Research intensity and knowledge transfer activity in UK universities". Research Policy, 41: 262-275.

HMSO, 1992. Further and Higher Education Act. HMSO, London.

Huggins, R., \& Izushi, H. (2013). "Knowledge-based development in leading regions across the globe: An exploratory analysis of the co-evolution of resources, capabilities and outputs". Urban Studies, 50(5), 1030-1048.

Huggins, R and Kitagawa, F (2011). "Regional Policy and University Knowledge Transfer: Perspectives from Devolved Regions in the UK". Regional Studies, 46(6) 817-832.

Huggins, R. and Williams, N. (2011). "Entrepreneurship and regional competitiveness: The role and progression of policy." Entrepreneurship \& Regional Development, 23 (9-10): 907-932.

Hülsbeck, M.; Lehmann, E.E. and Starnecker, A. (2013) "Performance of technology transfer offices in Germany". Journal of Technology Transfer, 38:199-215.

Huyghe, A. and Knckaert, M. (2014). "The influence of organisational culture and climate on entrepreneurial intensions among research scientists". Journal of Technology Transfer, advanced access.

Jacob, M., Lundqvist, M. and Hellsmark, H. (2003). "Entrepreneurial transformations in the Swedish University system: the case of Chalmers University of Technology". Research Policy, 32: $1555-1568$.

Jaffe, A.B. (1989) "Real effects of academic research". The American Economic Review, 79(5): $957-$ 970.

Kitagawa, F. (2004). "Universities and regional advantage: higher education and innovation policies in English regions". European Planning Studies, 12(6): 835-852.

Kitagawa, F and Lightowler, C (2013) "Knowledge Exchange: A comparison of policy, incentives and funding mechanisms in English and Scottish Higher Education" Research Evaluation, 22(1): 1-14.

Klofsten, M. and Jones-Evans, D. (2000). "Comparing Academic Entrepreneurship in Europe The Case of Sweden and Ireland." Small Business Economics, 14: 299-309.

Landry, R.; Saïhi, M.; Amara, N. and Ouimet, M. (2010) "Evidence on how academics manage their portfolio of knowledge transfer activities". Research Policy, 39: 1387-1403. 
Laursen, K.; Reichstein, R. and Salter, A. (2011) "Exploring the Effect of Geographical Proximity and University Quality on University-Industry Collaboration in the United Kingdom". Regional Studies, 45(4): 507-523

Lawton Smith, H., and Bagchi-Sen, S. (2012). "The research university, entrepreneurship and regional development: Research propositions and current evidence". Entrepreneurship \& Regional Development, 24(5-6): 383-404.

Lee, S. (2007). Structural Equation Modeling. A bayesian approach. John Wiley \& Sons, Ltd

Link, A.N., Scott, J.T. and Siegel, D.S. (2003). "The economics of intellectual property at universities: an overview of the special issue". Int. J. Ind. Organ, 21: 1301-1322.

Little, T. (2013). Longitudinal Equation Modelling. Guilford Press.

Lundvall, B. (2007). National innovation systems - Analytical concept and development tool. Industry and Innovation, 14 (1): 95-119.

Martin, B. R. (2003). The changing social contract for science and the evolution of the university. In A. Geuna, A. J. Salter \& W. E. Steinmueller (Eds.) Science and Innovation: Rethinking the rationales for funding and governance. Cheltenhan, UK: Edward Elgar Publishing Limited.

Martinelli, A.; Meyer, M. and von Tunzelmann, N. (2008). "Becoming an entrepreneurial university? A case study of knowledge exchange relationship and faculty attitudes in a medium sized, research oriented university". Journal of Technology Transfer, 32 (2): 259-283

McCormack, J.; Propper, C. and Smith, S. (2014). "Herding cats? Management and university performance" The Economic Journal. DOI: 10.1111/ecoj.12105

Metcalfe, J.S. (2010). "University and business relations: Connecting the knowledge economy." Minerva, 48: 5-33.

Molas-Gallart, J., Salter, A., Pastel, P., Scott, A. and Duran, X. (2002). Measuring Third Stream Activities. Final Report to the Russell Group of Universities. Science and Technology Policy Research (SPRU), University of Sussex. Brighton (UK).

Moretti, E. (2004). "Estimating the social return to higher education: evidence from longitudinal and repeated cross-sectional data." Journal of Econometrics, 121: 175-212.

Mowery, D. \& Sampat, B. N. (2005) Universities in national innovation systems, in: D. C. M. Jan Fagerberg \& R.R. Nelson (Eds) The Oxford Handbook of Innovation (Oxford: Oxford Univesity Press).

Mowery, D.C. and Shane, S. (2002). Introduction to the special issue on university entrepreneurship and technology transfer. Manage Sci, 48 (1): v-ix.

Nedeva M. (2007) New tricks and old dogs? The 'third mission' and the re-production of the university, in Epstein D., Boden R., Deem R., Rizvi F. and Wright S. (Eds) Geographies of knowledge, geometries of power: framing the future of higher education, pp. 85-105. London, Routledge.

OECD (2004). Patents and innovation: Trends and policy challenges. OECD. Paris.

OECD (2007) Higher education and regions: globally competitive, regionally engaged. Paris, OECD/IMHE

Olmos-Peñuela, J, Molas-Gallart, J and Castro-Martínez, E (2013) “Informal collaborations between social sciences and humanities researchers and non-academic partners". Science and Public Policy. First published online October 17, 2013. DOI:10.1093/scipol/sct075.

Olsson, U. H.; Foss, T.; Troye, S.V. and Howell, R.D. (2000). "The Performance of ML, GLS, and WLS Estimation in Structural Equation Modeling Under Conditions of Misspecification and Nonnormality". Structural equation modeling, 7(4), 557-595.

PACEC/ Centre for Business Research (CBR) (2009) Evaluation of the effectiveness and role of HEFCE/OSI third stream funding: Culture Change and Embedding Capacity in the Higher Education Sector Towards Economic Impact. Report to HEFCE by PACEC and the Centre for Business Research, University of Cambridge. 2009/15.

Peer, V. and Penker, M. (2014). Higher Education Institutions and Regional Development A Metaanalysis. International Regional Science Review, 14. 
Perkmann, M., Tartari, V., McKelvey, M., Autio, E., Brostrom, A., D'Este, P., and Sobrero, M. (2013). "Universities and the third mission: a systematic review of research on external engagement by academic researchers". Research Policy, 42, 423-442

Perry, B. and May, T. (2010) "Urban knowledge exchange: devilish dichotomoies and active intermediation" International Journal of Knowledge-based Development, 1(1/2): pp. 6-24.

Perry, B. E. T. H. (2012). Excellence, relevance and the construction of regional science policy: Science frictions and fictions in the north west of England. In In R. Pinheiro, P. Benneworth \& G. A. Jones (Eds.) Universities and Regional Development: An Assessment of Tensions and Contradictions. London: Routledge pp. 105-123.

Philpott, K.; Dooley, L.; O'Reilly, C. and Lupton, G.. 2011. “The entrepreneurial university: Examining the underlying academic tensions". Technovation, 31 (4): 161-170

Pinheiro, R., Benneworth, P., and Jones, G. A. (2012). Universities and Regional Development: An Assessment of Tensions and Contradictions. London: Routledge.

Pinto, H., Fernandez-Esquinas, M. and Uyarra, E., (2013). “Universities and Knowledge-Intensive Business Services (KIBS) as Sources of Knowledge for Innovative Firms in Peripheral Regions". Regional Studies (ahead-of-print), 1-19.

Polt, W.; Rammer, C.; Gassler, H.; Schibany, A. and Schartinger, D. (2001) "Benchmarking industry-science relations: the role of framework conditions". Science and Public Policy, 28(4), 247-258.

Ponds, R., Van Oort, F., and Frenken, K. (2010). “Innovation, spillovers and university-industry collaboration: an extended knowledge production function approach". Journal of Economic Geography, 10(2), 231-255.

Power, D. and Malmberg, A. (2008). "The contribution of universities to innovation and economic development: in what sense a regional problem?" Cambridge Journal of Regions, Economy and Society, 1 (2): 233-245.

Rafferty, M. (2008). "The Bayh-Dole Act and university research and development." Research Policy, 37(1): 29-40.

Rodríguez-Pose, A. (2013) “Do Institutions Matter for Regional Development?” Regional Studies, 47:7, 1034-1047. DOI: 10.1080/00343404.2012.748978

Romer, P.M. (1990). "Endogenous technological change." Journaol of Political Economy, 98: 71102.

Sánchez-Barrioluengo, M. (2014). "Articulating the 'three-missions' in Spanish universities". Research Policy, 43: 1760-1773

Sánchez-Barrioluengo, M., Uyarra, E. and Kitagawa, F. (2014). “Understanding the Third Mission: changes in strategies, capabilities and resources" Paper presented at the Annual Eu-SPRI Conference: Science \& Innovation Policy Dynamics, Challenges, Responsibility \& Practice (Manchester, 18-20 June 2014)

Scott W.R. (1995). Institutions and Organizations. Beverly Hills, CA: Sage

Siegel, D. S., Veugelers, R. and Wright, M. (2007) "Technology transfer offices and commercialization of university intellectual property: Performance and policy implications". Oxford Review of Economic Policy, 23(4): 640-660.

Siegel, D., Waldman, D. and Link, A.N. (2003). "Assessing the impact of organizational practices on the productivity of university technology transfer offices: an exploratory study". Research Policy, 32 (1): 27-48.

Siegel, D., Waldman, D. and Link, A.N. (2004). "Toward a model of the effective transfer of scientific knowledge from academicians to practitioners: qualitative evidence from the commercialization of university technologies". Journal of Engineering and Technology Management 21: 115-142.

Tartari, V. and Breschi. S (2012) "Set them free: scientists' evaluations of the benefits and costs of university-industry research collaboration". Industrial and Corporate Change, 21 (5): 1117-1147.

Teichler, U. (1988). Changing patterns of the higher education system. The experience of three decades. London: Jessica Kingsley. 
Teichler, U. (2004). Changing structures of the higher education systems: The increasing complexity of underlying forces. In: UNESCO Forum Occasional Paper Series Paper No. 6 Diversification of Higher Education and the Changing Role of Knowledge and Research.

Thompson, E. P. (1970). Warwick University. Ltd. Penguin.

Trippl, M.; Sinozic, T. and Lawton Smith, H. (2014). "The role of universities in regional development: conceptual models and policy institutions in the UK, Sweden and Austria". CIRCLE Publications, Paper no. 2014/13. Available at:

http://www.circle.lu.se/upload/CIRCLE/workingpapers/201413 Trippl et al.pdf

Uyarra E (2010) "Conceptualizing the Regional Roles of Universities: Implications and Contradictions". European Planning Studies, 18: 1227-1246.

Wallsten, S. (2001). "An empirical test of geographic knowledge spillovers using geographic information systems and firm-level data." Regional Science and Urban Economics, 31: 571599.

Watson, D. (2007). Managing Civic and community engagement, Milton Keynes. Oxford University Press.

Whitley, R. (2008). Universities as Strategic Actors: Limitations and variations. In: Engwall, L. and Weaire, D. (Eds.) The University in the Market. London. Portland Press. 23-37.

Williams, L.J., Gavin, M.B. and Hartman, N.S. (2004). Structural equation modeling methods in strategy research: applications and issues. In Ketchen, Jr., D.J., Bergh, D.D. (Eds.), Research Methodology in Strategy and Management, vol. 1. Elsevier, Oxford, pp. 303-346.

Wright, S. (1934). "The method of path coefficients". Annals of Mathematical Statistics, 5 (3): 161-215

Yigitcanlar, T. (2010). "Making Space and Place for the Knowledge Economy: Knowledge-based Development of Australian Cities." European Planning Studies, 18(11), 1769-1786. 